\title{
GARBAGE COLLECTION IN STATE MARANHÃO (BRAZIL)
}

\author{
Deracilde Santana da S. Viégas ${ }^{1, *}$; Gildevan Nolasco Lopes ${ }^{1}$
}

1Doctorate in Program of Biodiversity and Biotechnology Network of the Legal Amazon- BIONORTE. Federal University of Maranhão. São Luís, MA. Campos Universitário do Bacanga - Centro de Ciências Exatas e Tecnologia Av. dos Português, s/n - São Luís/MA - CEP: 65085-580.

${ }^{*}$ Corresponding author: cindy.g.f@hotmail.com

Received: Sep. 11, 2017 - Accepted: Sep. 22, 2017

DOI: http://dx.doi.org/10.22615/2526-1746-jgm-2.3-7930

\begin{abstract}
The state of Maranhão presents a situation of vulnerability in relation to garbage collection. Garbage collection data show that municipalities in Maranhão do not collect garbage properly. We examined the relationship between Gross Domestic Product, Population Size and Garbage Collection Data. The database analyzed was obtained from the Demographic Census of 2000 and 2010 conducted by the Brazilian Institute of Geography and Statistics (IBGE). The results obtained show that the municipalities of Maranhão provide the garbage collection service for the majority of their population, since the average proportion of residents served by garbage collection considering the different municipalities was 99.4\% ( $\mathrm{Min}=95.4 \%$, Max = 99.9\%). Comparing data for the years 2010 and 2000, a significant increase in the service of residents by the garbage collection system was observed for most municipalities. However, the demand for the service is still greater than the supply when the issue is garbage collection, although discrete advances have been made by society, the need for investment and regional planning with local articulations of actions to solve this problem.
\end{abstract}

Key words: garbage collection, Maranhão State, Solid wastes.

\section{COLETA DE LIXO NO ESTADO DO MARANHÃO (BRASIL)}

RESUMO: O estado do Maranhão apresenta uma situação de vulnerabilidade em relação à coleta de lixo. Os dados de coleta de lixo mostram que os municípios do Maranhão não coletam o lixo adequadamente. Examinamos a relação entre o Produto Interno Bruto, o Tamanho da População e os Dados de Coleta de Lixo. O banco de dados analisado foi obtido no Censo Demográfico de 2000 e 2010 realizado pelo Instituto Brasileiro de Geografia e Estatística (IBGE). Os resultados obtidos mostram que os municípios do Maranhão fornecem o serviço de coleta de lixo para a maioria de sua população, uma vez que a proporção média de residentes atendidos pela coleta de lixo considerando os diferentes municípios foi de 99,4\% (Min = 95,4\%, Max = 99,9\%). Comparando dados para os anos 2010 e 2000, observou-se um aumento significativo no serviço dos residentes pelo sistema de coleta de lixo para a maioria dos municípios. No entanto, a demanda pelo serviço ainda é maior do que a oferta quando o problema é a coleta de lixo, embora tenham sido feitos progressos discretos pela sociedade, a necessidade de investimento e planejamento regional com articulações locais de ações para resolver esse problema.

Palavras-chave: coleta de lixo, Maranhão, resíduos sólidos. 


\section{INTRODUCTION}

The environment has suffered great consequences due to the disorderly increase of the garbage produced daily around the world; this reality is not different for Maranhão. Cities do not have adequate planning for the large occupation of large social groups, resulting in an inadequate distribution and occupation of the urban space that generates numerous social problems, such as the irregular disposal of garbage.

Maranhão is a federal unit of Brazil with more than 6.95 million people distributed in 217 municipalities (IBGE, 2017). When these locations are compared to other cities in the country, they still have a primitive management of solid waste without an adequate treatment, such as garbage dump and controlled landfills. According to the Solid Waste Scenario in Brazil (2013), the amount of garbage has continuously grown at a rate of 749 thousand tons per year, a large part of which is destined for garbage dump and controlled landfills. From the environmental point of view, the controlled landfills and garbage dumps are similar since they do not have the set of systems necessary for the protection of the environment and public health. For the municipalities of Maranhão, where there is inadequate waste management and a lack of awareness of the resulting impacts, this work is justified by presenting information to society on how the garbage collection in Maranhão is occurring and generating knowledge on the subject.

The latest data available in 2012 provided by the National Sanitation Information System (SNIS) point to São Luís among the Brazilian capitals as the worst average of kilograms of total garbage collected daily per person (BRASIL - Ministério das Cidades, 2016). The state of Maranhão is the least garbage collection in Brazil, according to a survey by IBGE (2010). In a survey released by IBGE, the state appears with the worst rate of garbage collection in the country. Just over half the garbage produced in the 217 municipalities is collected. In São Luís, each inhabitant produces $739 \mathrm{~kg}$ of garbage in one year. Considering a current population of $1,000,000$ people in this city, a total of 749,000 tons of garbage are produced annually. A problem that is aggravated by the lack of effective public policies for the collection and destination of garbage produced in the cities of Maranhão.

As in the whole of Brazil, the state still has difficulty complying with the National Solid Waste Policy (PNRS), as provided by Law $\mathrm{N}^{\circ}$ 12305/2010. In accordance with Federal Law $N^{\circ}$ 12305/2010, municipal solid waste includes: 1) Household Waste: those originating from domestic activities in urban dwellings; 2) Urban Waste: those originating from sweeping, cleaning of public places and roads, as well as other urban cleaning services (BRASIL - Ministerio do Meio Ambiente, 2014). Of the 217 municipalities in Maranhão, only $20 \%$ closed their dumps, and only $30 \%$ elaborated the waste management plan. According to data from the Social Observatory of São Luís, in a comparison between the 27 capitals of Brazil, São Luís is the one that produces the most garbage daily. Without adequate compliance with the guidelines defined in the PNRS since 2010, the volume of garbage can become catastrophic for the city.

Educating the population about the impacts of litter becomes urgent. At a certain moment, public power and the population 
will have to join forces to solve the problem of urban waste. This shows a current demand for environmental education for the population in order to guarantee a sustainable way of life in society, since the lack of solid waste management affects the development of the state (SOUZA and SOARES, 2017).

It should also be noted that, without efficient selective collection, the materials are damaged and cannot be reused or recycled. This does not depend only on the initial phase of reception of what is discarded. In order to advance in this sector and to obtain successful indexes, it is indispensable a different tax treatment to these materials with stimulus to the garbage processing industry. Since, recycling industries need to be able to absorb and reinsert as raw material, what was discarded as waste. It is necessary to seek an effective response to the great challenge of the moment: to ensure a proper management and destination for materials discarded by society (NUNES et al., 2015).

The solutions are already widely known, the main ones being: the elimination of "dumps": 1) The implementation of sanitary landfills; 2) The implementation of selective collection systems; 3 ) The establishment of reverse logistics systems with the responsibility of producers; 4) and the feasibility of waste recovery and recovery plants. In this way, the work aims to contribute to the generation of information regarding the collection of garbage in Maranhão, presenting the data and contributing to the competent institutions together with society draw plans and together improve the numbers shown in the collection.

\section{MATERIAL AND METHODS}

The research universe was composed of the 217 municipalities that comprise the state of Maranhão. The information base was composed of secondary data obtained from IBGE censuses for the period 2000 and 2010 (IBGE, 2017). The information collected was the Population Size of municipalities, Gross Domestic Product (GDP) and the number of residents who are served by the garbage collection service.

The spatial analysis of the distribution of households with garbage collection was performed through the arithmetic mean data of the number of residents who are served by the garbage collection service between the years 2000 and 2010. From this database and the location points of the Municipalities, this information was processed in software for the generation of distribution map of the distribution of households with garbage collection.

The relationship between the variables Population Size and Gross Domestic Product was verified with the number of residents who are served by the garbage collection service through the Pearson Correlation. To exclude the effect of population size on GDP, a residue analysis was performed between these variables. Therefore, the residues were correlated with the variable number of residents who are served by the garbage collection service.

To test the difference in the provision of garbage collection service between the years 2000 and 2010 was initially made the division between the number of residents who are served by the service of garbage collection by the population size for each municipality. 
From this information, the Mann-Whitney test was applied comparing the results between the two years.

\section{RESULTS AND DISCUSSION}

In 2010, most of the municipalities (89\%) of Maranhão have less than 40,000 residents who have a garbage collection service. Already $04 \%$ of the municipalities of Maranhão have garbage collection serving more than 80.000 residents (Table 1 ). These municipalities are: Açailândia, Paço do Lumiar, Codó, Caxias, Timon, São José De Ribamar, Imperatriz and São Luís. Garbage collection is an indicator of urban cleanliness that refers to the presence or absence of this urban service. It is an important parameter, because areas of the city where there is no such service are conducive to higher levels of pollution, since the population discards in other ways: burning, grounding, rivers and streams, among others. Thus, it is recommended that small municipalities should invest in solid waste management in order to ensure the regular collection of waste, the correct disposal of solid waste and the reduction of visual pollution due to garbage while its demand is still low.

Table 1. Frequency table of municipalities that have the garbage collection service. The classes comprise the different numbers of inhabitants that are served by the service. $\mathrm{F}=$ Absolute Frequency of Municipalities; $\mathrm{Fr}(\%)=$ Relative Frequency in Percentages.

\begin{tabular}{ccccccc}
\hline \multirow{2}{*}{ Classes } & \multirow{2}{*}{ Interval } & \multicolumn{2}{c}{ Year 2000 } & \multicolumn{2}{c}{ Year 2010 } & $F_{r}(\%)$ \\
\hline I & $0-40.000$ & 194 & 89 & 189 & 87 \\
II & $40.000-80.000$ & 15 & 07 & 18 & 09 \\
III & $80.000-100.000$ & 08 & 04 & 11 & 05 \\
\hline
\end{tabular}

Source: IBGE - Demographic Census of 2000 and 2010.

The municipalities with high demands for the service of garbage collection are the localities that are in large urban centers. This conclusion can be obtained from the spatial analysis of the "hotspot" on the map obtained from the number of households with garbage collection in relation to the total number of households in the census tract (Figure 1). This ratio is equivalent to the density of the garbage collection and represents the areas of the city with the highest and lowest level of garbage collection per inhabitant. The map shows the following "hotspot": I) North: Metropolitan Region of São Luís and its surroundings. II) South: Balsas and Alto
Parnaíba; III) East: Caxias and Timon; IV) West: Açailândia and Imperatriz. These municipalities comprise the localities located in class $V$ and $V I$ of Table 1 , that is, the $4 \%$ of the cities of Maranhão with high demand for the service of garbage collection. Considering the reality of high demand, these regions must adopt actions that allow the correct management of the solid waste sector, such as the installation of sanitary landfills.

The high density in urban centers may be related to the degree of urbanization and population size. A high correlation ( $p<0.01 ; r$ $=0.99$ ) was found between population size and garbage collection. The GDP of municipalities is related to the number of 
residents served by the garbage collection service $(p<0.001 ; r=0.86)$. However, when we removed the effect of population size through residue analysis, this relation was not found ( $p>0.05 ; r=0.04)$. In this way, it was verified that the demand for the garbage collection service is related to the population size and that, disregarding this variable, the increase in the GDP does not represent an increase in the proportion of residents served by the garbage collection service. This information is important for the management of solid waste, since it, points out that municipal managers must be attentive to the demographic data of their municipalities, as it leads to greater demand for services and government resources.

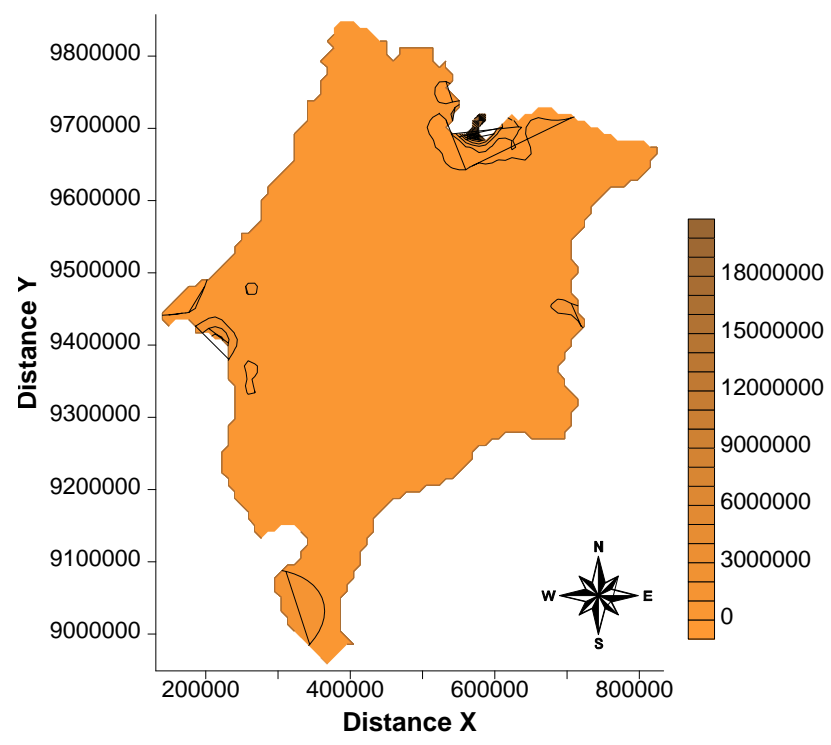

Figure 1. Map of the distribution of the number of residents with garbage collection service (Source: IBGE - Demographic Censuses of 1991, 2000 and 2010).

The municipalities of Maranhão provided the garbage collection service for the majority of their population, because the number of residents served by the garbage collection service, an average proportion of $99.4 \%$ was obtained $($ Min $=95.4 \%, \operatorname{Max}=99.9 \%$ ) In relation to the population size. Comparing data for the years 2010 and 2000, a significant increase in the proportion of garbage collection network was observed for most municipalities (Class I: $p<0.01, U=7092$, Class II: $p<0.05, U=8250)$. However, for Class III municipalities, there were no significant differences between the two periods ( $p$ > 0.05, $U=40$ ). Thus, municipalities that present a high demand for garbage collection services may not have followed the population increase.

Among the studied municipalities, the city of São Luís stands out, as it presented the greatest demand for garbage collection service compared to other localities. The city has the highest GDP $(R \$ 18,232,790.20)$ and the largest population (1,014,837 inhabitants) in all of Maranhão. In the year 2000 the capital had 86,608 residents served by the garbage collection service, already in 2010 that number increased to $1,005,558$, representing a $16 \%$ increase in demand for this service. Considering the relation of this variable to the population size, in 2000 São Luís served $99.55 \%$ of its population, and in 2010, this number dropped to $99.09 \%$, representing a decrease of $0.46 \%$ in the number of garbage collection services. The information about São Luís evidences the results of this work, since it points out that the high demand for the service accompanied the population increase, however the proportion of people served did not increase and that despite having the highest gross GDP does not present the highest level of service provision In the state.

The Municipal Government of São Luís has carried out important actions in the improvement of garbage collection services. In 2015, the new Controlled Landfill of São Luís was inaugurated. In the same year began 
the selective collection of garbage in São Luís. After that were built two sheds so that the collectors agreed to cooperatives could carry out its work. However, even with the wide coverage of the urban cleaning service, it is possible to identify some areas in the city with large amounts of garbage on the ground, at the peripheral neighborhoods and along the banks of watercourses. These aspects indicate that the coverage of a given service is not enough to build healthy environments. This should be combined with environmental programs and other strategies that help overcome this urban problem.

\section{CONCLUSION}

From the collected data, it was possible to verify the vulnerability of the state when the matter is garbage collection, even in such modern times, inefficient and harmful ways are used in the garbage collection environment, even though discrete advances may occur of society.

The spatial analysis of the data obtained in this work allowed observing a scene of the reality of garbage collection for Maranhão. It was observed that the population size is the main variable correlated with the increase in the demand for garbage collection. Only a minority of the municipalities of Maranhão present more than twice the demand than the other localities of Maranhão. This information is essential for waste management in municipalities and the spatial analysis presented can be used for regional planning with local articulations of actions to solve the demand for the garbage collection service.
The selective collection, in turn, has not yet become a practice in the state, although it is an indispensable element to enable the recovery of the discarded materials and their subsequent referral to recycling and recovery processes. This situation brings considerable losses to Maranhão, since the adopted system is economically inefficient and misses the potential of material and energy resources present in the discarded waste.

Several social groups have already established parameters, and have followed the paths that allowed the different situations to be addressed and the interaction of the main stakeholders, whether public or private, to solve the problems caused by solid waste. Maranhão still lacks an institutional evolution and prioritization of this subject, through the commitment of society, who did not perceive the risks of their ignorance and omission on the subject.

\section{REFERENCES}

IBGE. 2010 INSTITUTO BRASILEIRO DE GEOGRAFIA E ESTATÍSTICA. Disponível em: http: <Estimativas da população residente nos municípios brasileiros com data em 1으 de julho de 2016> Acesso em: 18. Abril. 2017.

IBGE. 2010 INSTITUTO BRASILEIRO DE GEOGRAFIA E ESTATÍSTICA. Disponível em: http: <Quando o lixo do domicílio é coletado diretamente por serviço de empresa pública ou privada > Acesso em: 18. Abril. 2017.

IBGE. 2010. INSTITUTO BRASILEIRO DE GEOGRAFIA E ESTATÍSTICA. Disponível em: http: <Quando o lixo do domicílio era depositado em uma caçamba, tanque ou depósito, fora do domicílio, para depois ser coletado por serviço de empresa pública ou privada > Acesso em: 18. Abril. 2017. 
MINISTÉRIO DAS CIDADES (SNIS). 2016.

Disponível em: <

http://nossasaoluis.org.br/slz2014/metodolog ia.html> Acesso: 10. Abril 2017.

MINISTÉRIO DO MEIO AMBIENTE. 2014.

Disponível em: http: <

http://www.brasil.gov.br/meio-

ambiente/2014/08/tire-suas-duvidas-sobre-a-

politica-de-residuos-solidos> Acesso: 14.

Abril. 2017.

Nunes, P.B.; Santos, B.A.; Ferreira; R.L. 2015.

Educação Ambiental: A questão do lixo na agrovila princesa do Xingu, zona rural da cidade de Altamira-PA. Caderno Meio Ambiente e Sustentabilidade. v.6 n.4.

PANORAMA DOS RESÍDUOS SÓLIDOS NO BRASIL. 2013. ABRELPE. Sustentabilidade: evitando a produção do lixo doméstico e contribuindo para o meio ambiente revista. Gestão sustentável ambiental. Florianópolis, v. 5, n. 2, p. 814-828, out.2016/mar. 2017.

Souza, J.R.; Soares, B.R. 2017. Em busca de cidades saudáveis: metodologia de análise de indicadores ambientais urbanos em Uberlândia, Minas Gerais, v. 13, n.1. 